\title{
Assemblages of Living Together: Residential Cohabitation in Peri-urban Areas of Chengdu and Hyderabad
}

Liubing Xie

\section{(2) OpenEdition}

Journals

Electronic version

URL: https://journals.openedition.org/samaj/7334

DOI: $10.4000 /$ samaj.7334

ISSN: 1960-6060

Publisher

Association pour la recherche sur l'Asie du Sud (ARAS)

\section{Electronic reference}

Liubing Xie, "Assemblages of Living Together: Residential Cohabitation in Peri-urban Areas of Chengdu and Hyderabad", South Asia Multidisciplinary Academic Journal [Online], 26 | 2021, Online since 21 April 2021, connection on 11 May 2021. URL: http://journals.openedition.org/samaj/7334 ; DOl: https:// doi.org/10.4000/samaj.7334

This text was automatically generated on 11 May 2021.

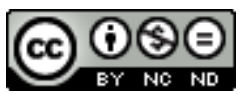

This work is licensed under a Creative Commons Attribution-NonCommercial-NoDerivatives 4.0 International License. 


\title{
Assemblages of Living Together: Residential Cohabitation in Peri- urban Areas of Chengdu and Hyderabad
}

\author{
Liubing Xie
}

\section{Introduction}

1 The current pace of urbanization in Asia, especially in China and India, is unprecedented in human history (e.g. Kanbur and Zhuang 2013; Swerts and Denis 2015; Xie, Swerts, and Pumain 2018). Much of the newly added urban population congregates in the peripheries of existing cities. In emerging urban scholarship such peripheries are no longer considered transitory spaces between the rural and the urban but rather distinct spaces worthy of attention in their own right (Caldeira 2017; Keil 2018, 2017; Ren 2021). Chinese and Indian cities such as Chengdu and Hyderabad-the focus of this paper-are increasingly globalizing their industrial, real estate, and tourist sectors, driven largely by the ambitions of their local and regional governments. With many of these globalizing projects situated in the peri-urban areas, the built environment is increasingly fragmented by both planned development and self-built communities. ${ }^{1}$ At the same time, the in-migration of professionals and rural migrants introduces constant changes to the social make-up of these spaces.

2 Various aspects of peri-urbanization have been observed and studied, including migration and the growth of informal settlements (Wu, Zhang, and Webster 2013), infrastructure-led growth (Schindler and Kanai 2021), e.g., through the development of hi-tech industrial parks (Kennedy 2007) or export zones (Jenkins et al. 2015), the spread of gated communities (Caldeira 2000; Deng 2017; Dupont 2016), and the interspersion of segregated residential areas (Garrido 2019). Research suggests that contemporary periurbanization processes do not follow the patterns observed in more established cities 
in the global North (Roy 2011; Wu 2020). In many parts of the global South, parallel urban processes of autoconstruction (Caldeira 2017) and the extension of new built-up spaces, e.g., gated complexes, produce an increasingly diverse ensemble of residents and communities in the peripheries. With disparate residential areas coexisting in the same vicinity, heterogeneous social groups that previously had little contact now reside in proximity and have to learn how to live with each other. The peri-urbanization processes in the global South thus embody a profound change in the urban social and material fabric. Residential cohabitation is the prism through which I propose to study this change. The term residential cohabitation refers here to the spatial proximity and shared living spaces of heterogeneous social groups in the increasingly fragmented and differentiated territories of peri-urban areas.

3 In the peripheries of both Chengdu and Hyderabad, I observed the physical proximity and boundary-making practices of middle-class residents, villagers and rural migrants, while asking the following questions. How do both the old and new residents of the urban peripheries adapt to the material and spatial conditions of the peri-urban spaces that are always in-the-making and constantly being altered? What are the new patterns of urban relationalities that emerge between these different social groups? The aim of the article is not to strictly compare specific attributes as similar or dissimilar variables, which is essential in variable-based comparison, but rather to take a midrange scope (Ong and Collier 2004) in order to explore the similar or different combinations of various elements, conditions and processes. Following Caldeira (2017), it aims to use juxtaposition of two seemingly different cases to consider how two different histories and sets of local conditions may lead to similar outcomes.

Research on this project started in 2018 and preliminary fieldwork was conducted in selected peri-urban areas of Chengdu and Hyderabad from December 2018 until the end of March 2019. ${ }^{2}$ I conducted approximately 30 semi-structured interviews with residents throughout different residential communities in Hyderabad, and approximately 30 semi-structured interviews with residents and officials from resident committees in the Chengdu case. ${ }^{3}$ The paper is intended as a starting point for future research, and the arguments made here aim rather to generate hypotheses than make wide-ranging claims about residential cohabitation in urban peripheries around the globe.

\section{Positioning the research}

5 A rich literature on peri-urbanization processes in the global South has emerged, much of which is devoted to explaining how global capital (Cowan 2015; Shen and Wu 2017) or state policies (Kennedy 2007; Shen and $\mathrm{Wu} 2017$ ) have contributed to these transformations. However, relatively few studies have paid attention to how the residents in these places interact with the evolving built environment and cohabite with other social groups in close proximity. Several exceptions stand out. In his research on the metropolitan area of Manila, Garrido (2019) has captured a "patchwork city" constituted of classed spaces, particularly gated enclaves and slums; and he argues that the proliferation of slums and enclaves and their subsequent proximity have worsened class relations and intensified unequal social interactions. Kundu (2016)'s work on Rajarhat New Town at the urban periphery of Kolkata has examined how the new town is fragmented into a formal network of roads and gated 
communities and dense urban villages with traditional housing patterns, and how the residents deploy various strategies of place-making in response to the loss of sense of place, including incremental expansion of houses, developing service sectors and organized resistance to land acquisition by both villagers and gated community residents. This article aims to continue the inquiry on forms of relationalities between heterogeneous social groups, particularly in relation to the transformation of the material and spatial conditions of peri-urban areas.

6 For reflecting on the association of the social and the material, the human and the technological elements that constitute peri-urban spaces, the notion of urban assemblages developed by Farias and Bender (2010) is particularly instructive. Latour (2005) suggests using the notion of "assembling" to understand how the social is formed through the associations between human and non-human actants. Introducing the Actor-Network-Theory ${ }^{4}$ into urban studies, Farias and Bender redefine the ontological status of the city as emergent processes of becoming through the multiple enactments of the social and the material at concrete sites and contexts of practice. Although departing from a very different tradition, Doreen Massey (2005) similarly suggests that space is a product of interrelations and spheres of coexisting heterogeneity in the processes of being made; that "multiplicity and space coconstitute each other" (p. 9). Both Farias and Bender and Massey note the coexistence of distinct trajectories and contemporaneous plurality, thus socio-material assemblages do not indicate a coherent whole, rather multiple becomings that are "discontinuous, even contradictory and mutually exclusive" (Farias and Bender 2010:14). Inspired by the concept of urban assemblages, this article proposes the notion of "assemblages of living together" to analyze the encounters and associations of heterogeneous social groups as well as the socio-spatial configurations and transformations that involve multiple material and social aspects in the urban peripheries of Hyderabad and Chengdu.

7 Based on preliminary field work, I identified three emblematic configurations of residential cohabitation in the peri-urban areas that I will explore here. The first is the interspersion of gated communities and autoconstructed communities, which is characterized by geographical proximity and physical separation, often marked by physical boundaries such as walls, gates, green areas and wide streets that demarcate the territories of residential communities; the second is the internal heterogeneities and separate living of different social, ethnic, and/or religious groups within the same residential areas, either gated communities or autoconstructed communities; the third is vertical cohabitation within the same building of petty landlord and tenants, mostly villagers who have developed multi-story rental housing and migrants who rely on them for cheap living space. I analyze how social processes interact with different types of residential communities in the peri-urban areas of Chengdu and Hyderabad to produce assemblages of living together, which are shaped and in turn mirror various trans-local and trans-human dynamics. I argue that each of these configurations of residential cohabitation is formed by the interweaving of globalizing forces and various situated local norms that are constituted historically (Ong and Collier 2004). 


\section{Assemblages of living together in peri-urban areas}

8 This research focuses on the lived experiences of the peri-urban residents, while situating them in the built environment that is lived, socialized, and in some cases, also built by the residents themselves. When heterogeneous groups of people converge and are concentrated in rapidly changing peripheral spaces, their mode of coexisting and vivre ensemble are entangled with the evolution of the patterns and spatial relations of the built environment. I propose the concept "assemblage of living together" to engage with the essential transformation of people's living and socializing practices in the peri-urban areas, the fragmentation of human territoriality and the co-habitation of social groups. Following Benjamin's (2008) critique on the literature that fosters overdeterminism of capital or market, I root my analysis in the materialities that interact with both global forces and local norms. I emphasize that space and built environment are not static and peri-urban residents are not only passive recipients of macro-level policies, instead, both space and residents are actants in assembling different material and social elements and shaping the (peri-)urban realities. And these realities are often plural, multiple and open-ended.

With a similar population size and similar positioning in the respective Chinese and Indian urban systems as regional centers, both Chengdu and Hyderabad stand as examples of the strategic role played by urban regions, and they have experienced extensive peri-urban development led by state initiatives over the past few decades (Das 2015; Qin 2015). A juxtaposition of the two city-regions or more precisely, selected neighborhoods in their peripheries can serve as a heuristic device to advance our understanding of peri-urbanization processes across national contexts.

As the capital of Sichuan province, Chengdu is a major city in Southwest China with a population of 16.6 million in 2019 in the metropolitan area. Since 2003, Chengdu Extended Urban Region (EUR) has piloted the program of "urban and rural coordination" (chengxiang tongchou fazhan) designated by the State Council. During this period, Chengdu's urban built area has radically expanded, as a result of real estate development and industrial parks in the peri-urban areas (Webster et al. 2004). As for the part of the Jinniu district where I conducted fieldwork, the redevelopment of villages began in 2006, and gained momentum in 2012 when Chengdu announced its ambitious Beigai (Renovating the Northern City) project. The local government claimed that the goal of the Beigai and the redevelopment of urban villages under the project was to regulate and regularize the urban peripheries and upgrade the living conditions of the residents in the area. Projects such as "Happy Valley," which I will discuss in detail, are part of the efforts to economically and aesthetically upgrade the Northern peripheral area.

11 Hyderabad is the $6^{\text {th }}$ largest metropolitan region in India with a population of 9.7 million, and serves as the capital of Telangana State. Starting in the late 1990s, regional political elites sought to transform greater Hyderabad into a dynamic economic region oriented toward global growth sectors through carefully designed industrial policies (Kennedy 2007). On the western peripheries of the city in particular, the establishment of HITEC City, a large-scale industrial park, and the Financial District within a newly created "Cyberabad Development Area" dramatically transformed the fabric of these peri-urban spaces (Das 2015). Two field sites were selected in this location. 
12 hinterland has formed a patchwork of differentiated spaces that accommodate various social groups, particularly local villagers, migrants from more far-flung rural areas, and "migrants" from both the core city and from other urban areas, professionals, but also semi-skilled workers attracted by employment opportunities in the rapidly expanding service industries. For instance, in the peripheries of Chengdu's Jinniu district, there has been a parallel development of themed amusement parks and high-end gated communities on the one hand, and dense urban villages on the other hand. The theme parks and residential gated communities have attracted middle-class residents from Chengdu's inner city, from other parts of Sichuan province and even from other provinces, who are seeking their "private paradise." ${ }^{5}$ Rural migrants who are essential for the dynamic economy of Chengdu can only afford to rent rooms in the villages in the vicinity, where local villagers have autoconstructed multi-story rental housing. Similarly, in the peripheries of Hyderabad's Financial District, global enterprises have attracted not only foreign expatriates, white-collar professionals, young graduates, but also rural migrants who work in the construction and service sectors. The large influx of personnel associated with these large enterprises has fueled the development of exclusive gated communities. At the same time, to accommodate the young entry-level professionals and the rural migrants, local landowners around Financial District have either constructed multi-story rental housing, similar to their Chinese counterparts, or collaborated with real estate companies to build paying-guest (PG) accommodation.

My research in Chengdu and Hyderabad suggests that the various configurations of assemblages of living together mirror broader global forces and local conditions, and at the same time articulate between the materiality of the built environment and the sociality of the various social groups present. The materiality of the built environment is the crystallization of the aspirations and agency of a specific set of actors; sociality is shaped by the geographical distance or separation that embodies social distance between individuals and social groups. Autoconstructed housing, for example, as Caldeira (2017) suggests, reflects the agency of residents: houses and neighborhoods grow little-by-little through improvising bricolage and complex calculation, thus becoming the material embodiment of the notion of progress. The physical boundaries erected in the peripheries constitute another example of the socio-material connection. Walls and wide roads stand as the crystallization of the attitudes-e.g., fear, distrust, scorn-of some residents towards others and the consequent effort to implement social separation or exclusion. The processes of transformation of peri-urban built environment are thus entangled with the formation and alteration of the relationalities between the different social groups. Therefore, I suggest that both spatial configurations and residents enact the assembling processes, and the materiality and sociality co-constitute each other. The living together of heterogeneous social groups involves multiple processes of assembling and becoming. I engage with three key social processes that emerged from my research and that occur in the various types of residential cohabitation and form three configurations of assemblages of living together in the peripheries: first, the constitution and reconstitution of heterogeneities in the new built environment by assembling different social groups who have had little contact with each other before, or reinforcing the preexisting social differentiation; second, the establishment or consolidation of physical and social borders, boundaries, social distancing through practices of border building and socio-economic exclusion; third, the development of highly unequal relations of interdependence based on 
economic connections such as landlord-tenant relations and employment relations. These social processes constitute three configurations of assemblages of living together, and they are mutually reinforcing. In the next sections I will discuss these processes for each of the three types of residential cohabitation.

\section{The interspersion of the autoconstructed communities and gated communities}

14 As indicated above, an interspersion of autoconstructed communities and up-market enclaves is observed in the peri-urban areas of many countries in the global South. Caldeira (2000) has analyzed a new segregation pattern of the proximity of fortified enclaves and working class autoconstructed communities in the peripheries of São Paulo. Garrido (2019) documents the fragmentation of Manila into an interspersion of spaces defined by class, particularly slums and middle-class enclaves. In China and India, large-scale projects such as Special Economic Zones (SEZs), industrial parks, entertainment parks driven by both globalization and state policies have given rise to new urban spaces, driving up the real estate prices of surrounding areas and attracting both the rich and the poor to live and work there. The interspersion of the autoconstructed communities and gated communities is associated with the first configuration of assemblage of living together, which is the co-production of the official planning regimes and the peri-urban residents' agency and calculation in capturing the use value of the land or the real estate surplus value. Moreover, the various practices of boundary building demarcate spaces of separate socialization, and are emblematic of strategies to control space and people (Sack 1986). ${ }^{6}$ In this section, I will explore both types of development in Chengdu and Hyderabad for outlining the heterogeneous and interconnected peri-urbanizing processes and the formation of socio-spatially divided and interspersed peri-urban landscape.

\section{Living together around a global tourist destination in Chengdu}

15 At the fringe of Jinniu district of Chengdu, one of the central projects for the official planning in the area is "Happy Valley," a themed amusement park modeled after western theme parks. Chengdu has been promoting its image as a global destination for tourism with its abundant natural and cultural heritage sites. ${ }^{7}$ As part of the "Happy Valley" project, a series of gated communities were developed contiguous to the amusement park, advertising a lifestyle of global standards (see Figure 1). Developed by Overseas Chinese Town Co., Ltd, a large state-owned company, ${ }^{8}$ Happy Valley is one of the important projects of Chengdu's tourism industries. ${ }^{9}$ The development of the amusement park and associated gated communities has transformed the peripheries of Jinniu district from a largely rural area to a tourist destination with the highest (5A) ranking given by Chinese Administration of Culture and Tourism. However, situated among and beside the world-class tourist attraction and residential areas are urban villages, a situation which exhibits the persistence of rural administration and the dual land system (He et al. 2010; Wu et al. 2013; Zhou and Ai 2016), and the sociality that is organized by the rural collectives (Zhang et al. 2003; Hsing 2010; Zhou and Ai 2016). The tensions between the globalized western-style gated communities and urban villages are partially reconciled by the city's endeavor to redevelop urban villages into 
resettlement housing communities that resemble gated communities in many aspects, e.g. high-rise apartment complexes (see Figure 2). ${ }^{10}$

Figure 1. The OCT gated community and the artificial lake that separates it from the rest of the urban peripheries in Jinniu district, Chengdu ${ }^{11}$

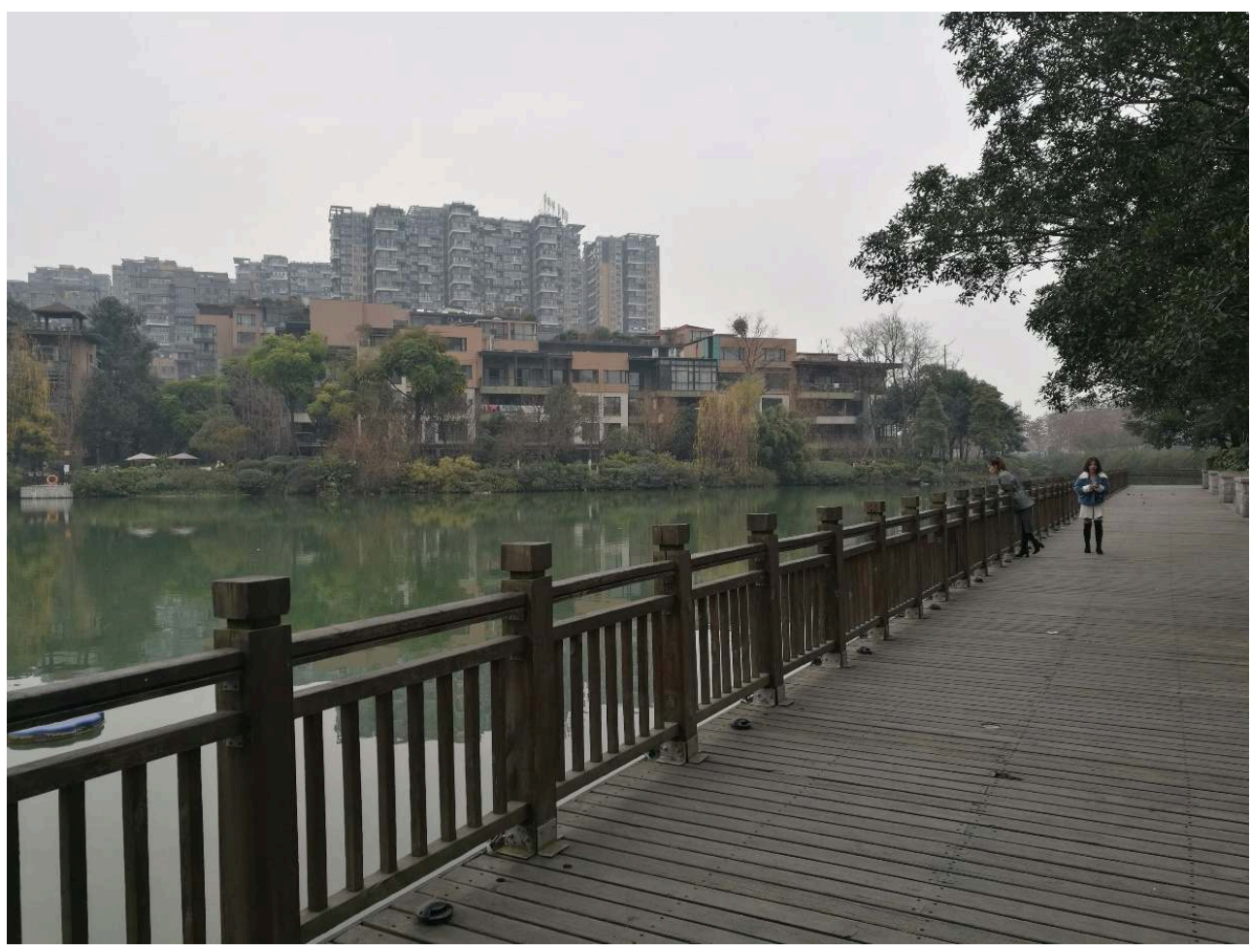

Figure 2. A resettlement housing community in Jinniu district, Chengdu

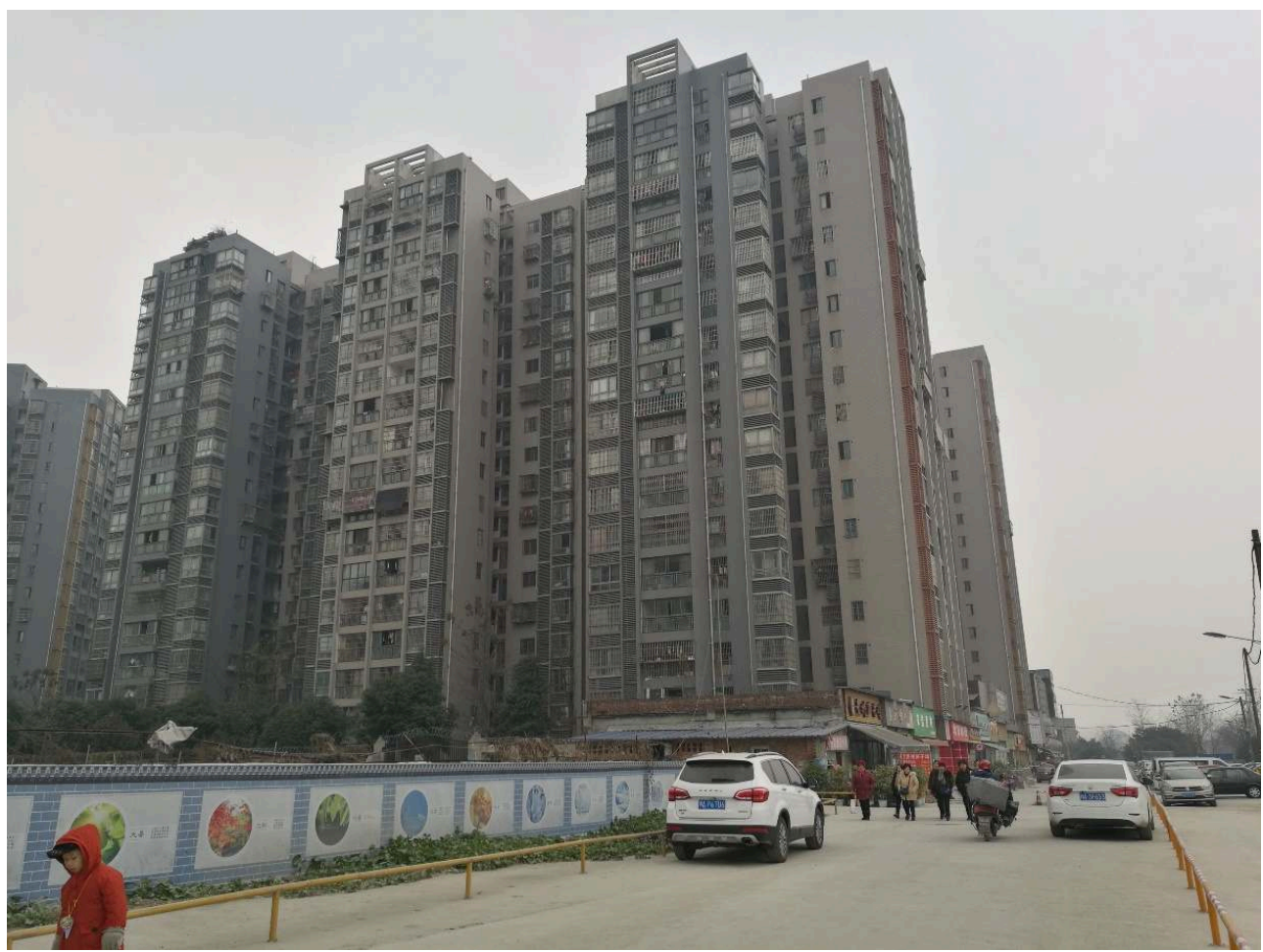



they also actively engage in the economic activities of the city. Huaxin village, once the largest urban village in Chengdu, was partly demolished during the time of my fieldwork. The villagers in Huaxin village vertically expanded their houses to rent extra rooms to migrants. ${ }^{12}$ The built environment became very dense, although not without order. The houses are organized in rows of three-story buildings, mostly in homogeneous colors of gray concrete and white ceramic tile (see Figure 3). Between the rows of the buildings are alleys and streets. The ground floor is equipped with sliding metallic doors, and can be used for commercial purposes. The tenants of the autoconstructed housing and the owners of the restaurants and shops at the ground floor are mostly from rural areas outside of Chengdu city. residents told me that in addition to regular markets and shops, monthly fairs were also very popular. A high-school gir ${ }^{14}$ who still lives in Huaxin village recalled the fair and its acrobatic performance with obvious nostalgia; an elderly barber-shop owner ${ }^{15}$ proudly told me that on the days of monthly fair, there would be still crowds till 10 o'clock at night. ${ }^{16}$ The small retail businesses in Huaxin village provided opportunities for encounters and interactions between the OCT residents and village residents, albeit unequal and limited. The vegetable and fruit markets were popular among OCT residents. The elders especially, who were used to frugal lifestyles, preferred to buy vegetables from the village markets, rather than more expensive supermarkets. Mrs. Zhang ${ }^{17}$ from the OCT gated community used to buy vegetables from Huaxin village twice a week and she liked the narrow streets and lively street scenes of the village. Some other OCT residents also liked to take a walk in Huaxin village. However, these limited encounters between villagers and OCT residents have been eliminated since the markets were demolished. 
Figure 3. The autoconstructed housing and a shop at the ground floor in Huaxin village, Chengdu

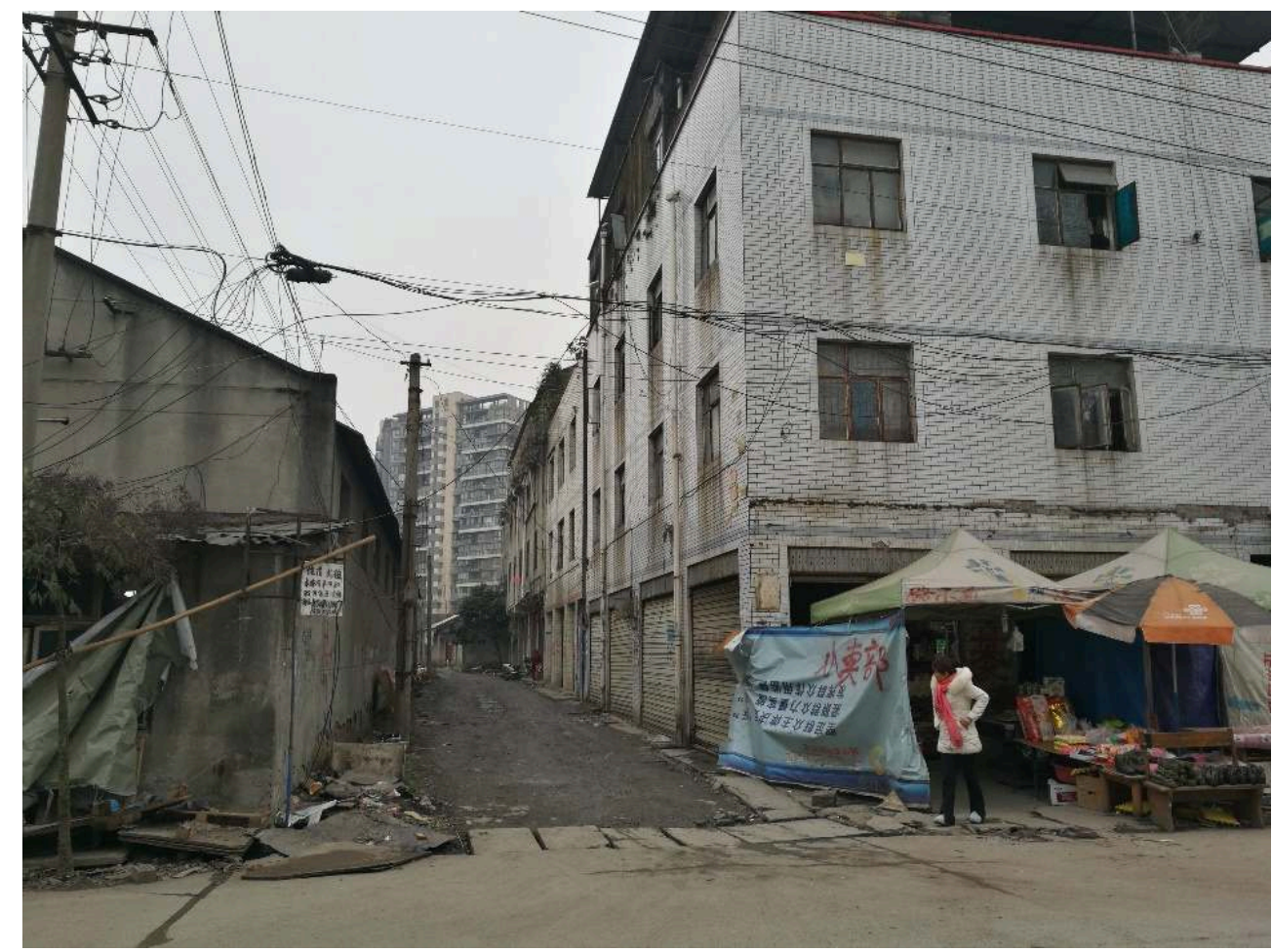

The planning of the world-class Happy Valley amusement park and gated communities set up clear boundaries with urban villages. At each gate of the enclave, an access control system is set up, allowing in its residents only, to whom pass cards are assigned; and a guard station was added with one or more guards, who surveil cars and people entering and leaving. Walls are not only used to separate the gated communities from the urban villages, but also to circumscribe the territories of urban villages and hide them from the passers-by. When the redevelopment project of Huaxin village started around 2016, one of the first steps of the project was to build walls to enclose the previously open and lively Huaxin village. ${ }^{18}$ The bustling commercial activities of Huaxin village were thus silenced and the bulldozers transformed parts of the village into piles of brick pieces and cement blocks. Green belts are another, more sophisticated technique that is deployed to set boundaries. Along the major roads by the side of Zhuwa village, a strip of hills on which trees, bamboo and bushes are planted perfectly block the view of the urban village from the sight of passers-by. The green areas alongside the roads contribute to the beautification of the city as a world-class tourist destination, and at the same time to erase the sight of the urban villages that undermines such an image and status.

The planning of boundaries is further extended to primary education in the area. While children from the OCT gated community are given priority for the bilingual Golden Apple kindergarten and well-ranked Renbei primary school, both of which are part of the gated community project as per the school district system, the villagers' and migrants' children who live in neighboring urban villages and resettlement housing communities mostly go to Fansheng primary school, which is among the worst-ranked of all primary schools in Jinniu district. ${ }^{19} \mathrm{~A}$ young mother Mrs. $\mathrm{Liu}^{20}$ from the OCT said that part of the reason why they chose to buy an apartment in the gated community is so their children could attend the good schools that are associated with the OCT gated 
community. The differentiated schooling of the middle-class children of the OCT and the local village and migrant children exemplifies the spatialized inequality, and the corporeal politics of quality (suzhi) (Anagnost 2004). ${ }^{21}$ The differentiation of schooling has thus reproduced the spatial disparity of potential and value in the next generation. And the demarcation of rich and poor school districts corresponds to the patterns of interspersion of gated communities and autoconstructed communities characterized by geographical proximity and physical separation.

\section{Living together around hi-tech industrials in Hyderabad}

Hyderabad has been initiating a series of policies and projects to promote its economic development and global importance. Inspired by international models of infrastructure-led growth from East Asia and Southeast Asia, the political elites of Hyderabad sought to engage with the global market through carefully designed industrial policies and the provision of "world-class" infrastructure, which often takes the form of enclaves (Kennedy 2007; Prasad and Ramachandraiah 2008; Bunnell and Das 2010). My field site in Hyderabad is near the new Financial District, developed in the former village of Gachibowli, that houses various multi-national companies such as Microsoft, Infosys, Wipro, Capgemini, Polaris, and the prestigious Indian School of Business (Das 2015). The peri-urban landscape of Hyderabad is characterized by a patchwork of special purpose enclaves including gated communities and office building complexes, and autoconstructed communities of bastis and villages (Kennedy and Sood 2019; Sood and Kennedy 2020).

21 As mentioned above, the growing connections with the global flow of technology and capital have attracted expatriates and high-profile IT professionals, but also opened up the job markets for IT workers in entry-level positions. Moreover, with emerging companies and gated communities there are service job opportunities, such as security guards, drivers, domestic help and so on.

Ridge Estates is an established gated community, located near the Financial District, providing luxury living conditions for expatriates, middle and upper-middle class. It has 62 stand-alone villas, each with its own garden space and inhabited by a single family. The gated community is equipped with a well-managed utility supply, and amenities such as gyms, a swimming pool, tennis court, and kids' playground. Around half of the villas are inhabited by expatriates of French, American, Australian, and South Korean nationalities, the other half by Indian families. Many of the residents in Ridge Estates work in upper management positions in transnational companies, others practice law and medicine.

Mountain View is another gated community near the Financial District. In contrast to the low-density villas in Ridge Estates, Mountain View is comprised of many high-rise apartment buildings (see Figure 4). Within its gates, Mountain View has set aside a large strip of land between the high rises as the common spaces for the residents to congregate or walk around. The spacious roads inside the gated communities serve as walking and running tracks as well, protected from the dust and traffic of the public roads. While most of urban India is extremely deprived of public space, these private "public spaces" are especially valued by the residents. Like Ridge Estates, Mountain View is equipped with all sorts of sport facilities, the mere existence of which is a status symbol. In addition, there is a large supermarket within the complex, which includes 
an imported food section, featuring, for example, chocolates and wines from Europe. Moreover, the private management of all kinds of utilities is particularly valued by residents. Amit, a retired bank clerk who had been living in Mountain View for a year at the time of our interview, ${ }^{22}$ praised the private management of the utilities, which he felt suited senior residents like him. He noted that instead of having to go to different agencies to pay his bills, he just had to pay the management company of the gated community and call them when there were problems, and that they are much more efficient than public agencies. Most importantly, the private management of water and electricity allows uninterrupted services through storage and the use of backup generators.

Figure 4. The high-rise gated community of Mountain View, Hyderabad

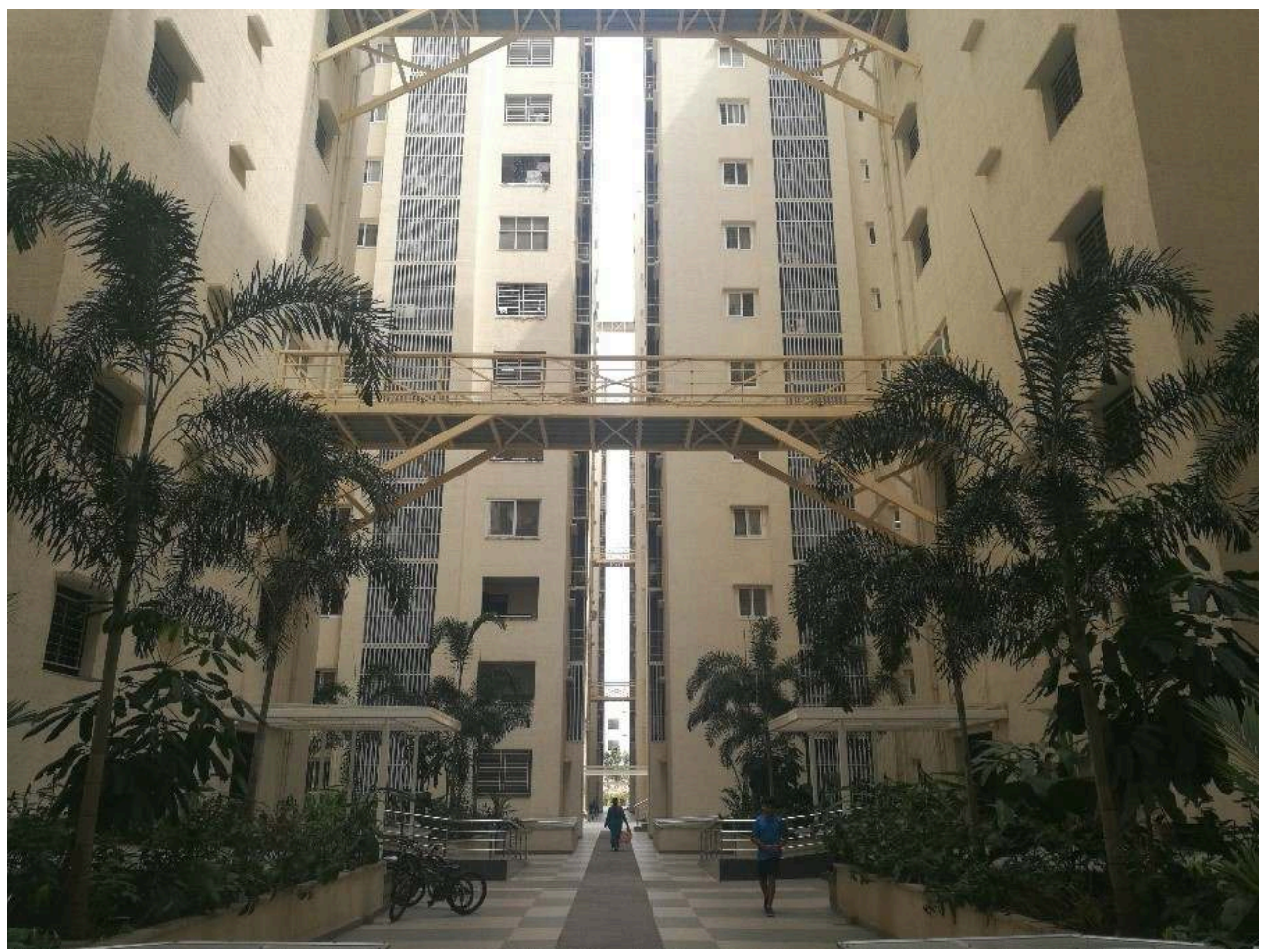

Similar to urban villages in the Chinese case, villages in the periphery of Hyderabad serve as one of the most important sources of affordable housing. To accommodate the large influx of both lower rank professionals and rural migrants, villagers have adopted similar strategies to build up three- to five-story rental houses like their counterparts in China (see Figure 5), and some of them also sold land to developers who have constructed paying-guest (PG) accommodation to rent mainly to young IT workers (see Figure 6).

In the village of Devenderpally (pseudonym) across the road from Ridge Estates, farmers used to own and cultivate plots of land. I was told that around the year 2000, some realtors and politicians who knew about the plans for a Financial District approached villagers, asking them to sell land. Some of these villagers used the money to construct rental houses for migrants on their residential plots, which they did not sell. Others villagers who did not accumulate enough capital from selling land partnered with developers to build PG houses. The agreement was that the revenue 
generated from the land and property would be evenly shared by the original landowner and the developers.

26 According to a member of the local panchayat, ${ }^{23}$ there now stand around 200 autoconstructed rental houses and 100 PG houses co-developed by developers and farmers. The rental houses and PG houses are built in rows and the streets between them are well-paved.

Figure 5. Autoconstructed housing with a courtyard in Devenderpally village, Hyderabad

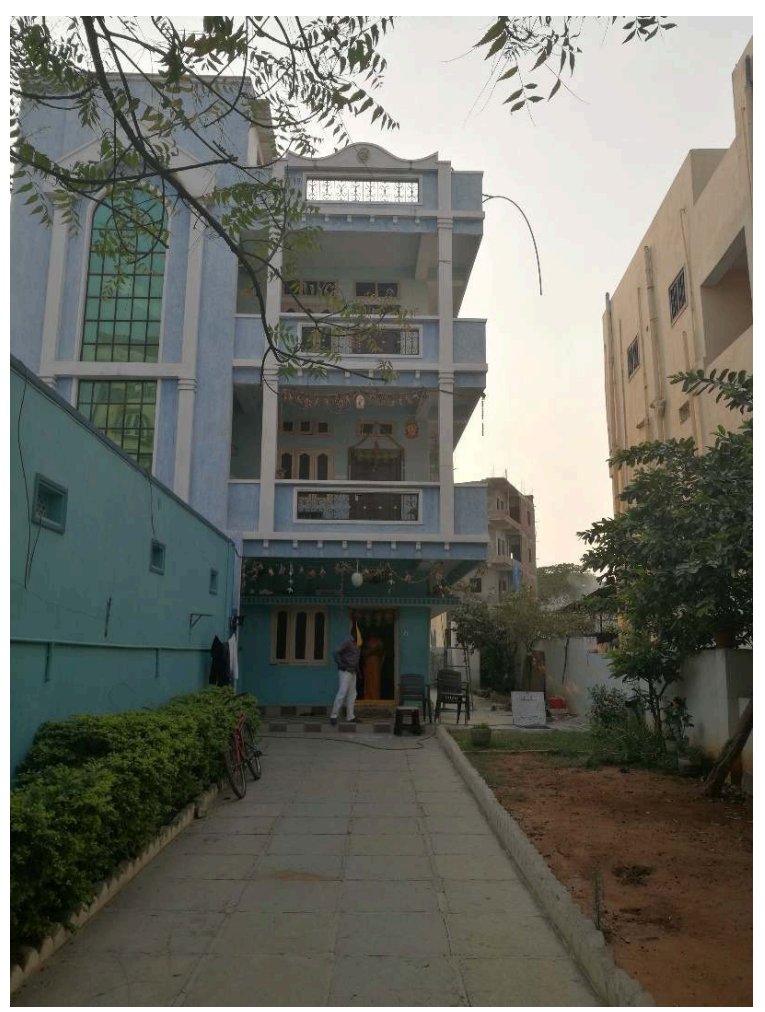


Figure 6. A paying-guest house in Devenderpally village, Hyderabad

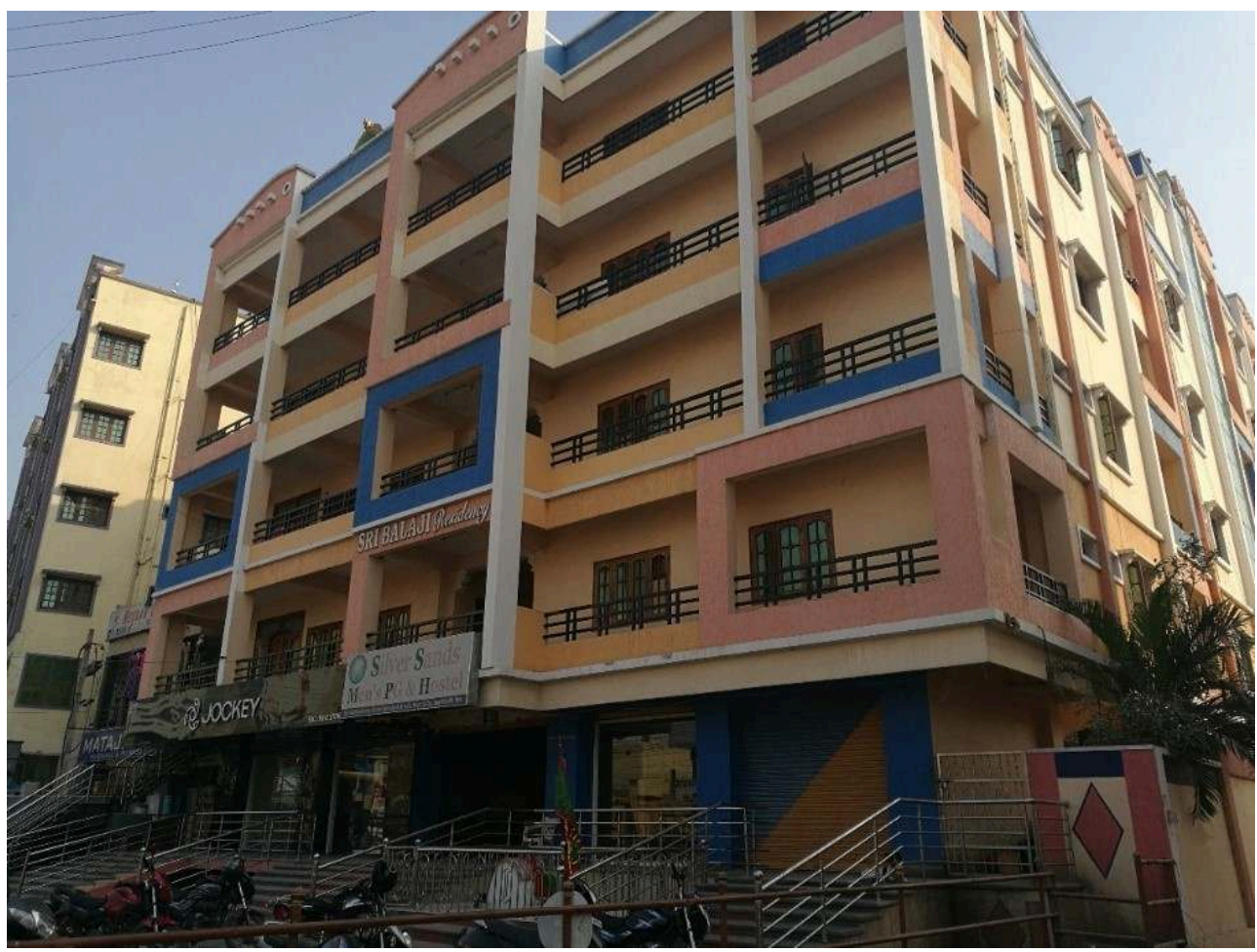

To summarize, in Chengdu and Hyderabad, different types of residential areas exist in close proximity; however, they are separated by various physical boundaries. Walls are the first type of boundaries that are built by gated communities to divide the inner and outer space, and to separate the community residents from the dusty and wide roads that are "unfriendly" to pedestrians. Among the several types of residential areas observed, the villages at the peripheries of Chengdu and Hyderabad are spatially and socially the most open housing communities, with high levels of population mobility, and generally not regulated or surveilled by public or private security systems. Wide roads and green belts are the second major physical barriers that delineate the boundaries of the different residential areas. In both cities, a common planning practice is to build wide main roads, sometimes accompanied by a strip of green area at each side. These roads often correspond to the boundaries of different types of residential communities.

\section{Internal heterogeneity within residential communities}

In this section, I will discuss internal heterogeneities within a given residential type, either gated communities or autoconstructed communities. It is commonly assumed that gated communities in the peri-urban areas are emblematic of a middle-class lifestyle. As Zhang (2010) and Wu (2010) suggests, middle class Chinese perceive gated communities as a private paradise; purchasing and moving into a gated community is to join a club based on middle-class status. In India, tapping into the middle class' aspiration for security, a healthy living environment, exclusivity, elitism and social homogeneity, secured enclaves have proliferated in major cities like Delhi (Dupont 2016). On the other hand, autoconstructed housing communities are often associated with informality and the congregation of the urban under-class (Wu et al. 2013; Bhan 2016; 
Roy 2009; Kochan 2015). This simplistic demarcation tends to neglect the heterogeneity of the residents within the same residential areas, either autoconstructed communities or gated communities. Based on my observations in Chengdu and Hyderabad, social heterogeneity is apparent not only between the residential communities, but within them, and inequalities are often inscribed according to various norms that are largely historically constituted. The politics and norms around various social categorizations such as religion, caste, class, rural/urban sensibilities ${ }^{24}$ shape residents' attitudes and subjectivities; in doing so, they order and reorder the spatial and social positioning of the bodies that are defined by these norms (e.g. Sandercock 2000; Young 2011). Another fracture line is drawn by homeownership. In this section, I introduce the second configuration of assemblages of living together of heterogeneous social groups within the same residential communities. Two processes are particularly prominent. The first is that the pre-existing heterogeneity and differences within the community is reinforced or reconstituted in this moment of social-spatial change. The second process involves the assembling of different social, ethnic, religious groups who had little contact earlier with each other. Both processes are entangled with a contemporaneous constitution of the built environment and the sociality within the residential communities.

It is well established that Indian villages are socially segmented along caste and religious lines, and that local caste configurations are a major determinant of access to land and other resources..$^{25}$ In Devenderpally village, I observed that the differential relations of residents from different caste groups with landed property have shaped their access to opportunities and consequently their residential conditions, status, and social relations. In particular, the relations between herders and farmers, the two main groups in the village, have undergone changes since the acceleration of the periurbanization processes in the area. The groups have evolved different strategies to materialize and maintain prosperity: while the farmers sought to buy land, the herders have increased the size of their buffalo herds. However, with the prosperity of the farmers' group in real estate and some other small businesses leveraged by the selling of land since the 2000s, the farmers are increasingly benefiting from the real estate market and the disparity of wealth and income between the two groups has been widening.

The herders are increasingly marginalized at a time when land value is drastically increasing in the area. Most of these families still live in one-story houses, with a courtyard for their buffalos (see Figure 7). In this part of the village, buffalos can be seen over the lows walls that surround the yard, and manure is sometimes dried in the yard to be used as fuel. The lanes between houses are not paved, in contrast to the wellpaved roads in the remaining part of the village. Seeing the success of the farmers, some families from the herder caste have also started to participate in the real estate market. However, due to their relative lack of land resources, they were only able to sell or rent part of their residential plots to developers. 
Figure 7. A herder's house with the buffaloes in Devenderpally village, Hyderabad

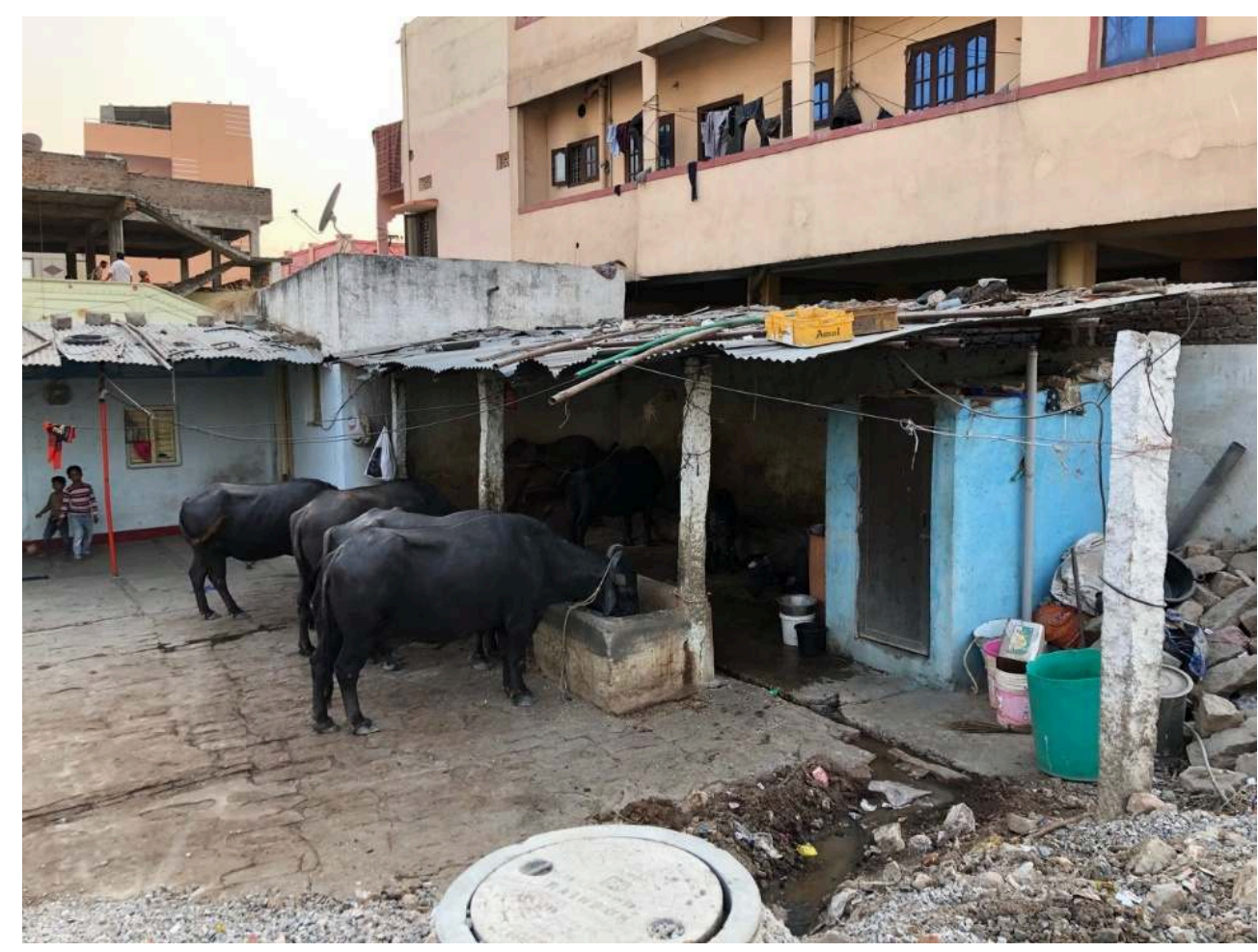

Image credit: L. Kennedy, 2020.

31 Thus, over time the village's two main groups have become increasingly distanced socially because of the increasing gap in wealth. Coexisting in the village, the herders and farmers reside in separate spaces and the interactions between the two groups has decreased. As a middle-aged herder ${ }^{26}$ told me, the members of his family do not have much interaction with farmers anymore; they are not even invited to festival celebrations and weddings. He remarked that the farmers keep their distance from the herders' places as they dislike the smell of buffalos. He then suggested that the farmers kept their distance from them for the same reason, because they also stink. The herder seemed to be saying that the farmers now consider themselves superior to the herders, and that buffalo rearing has become socially stigmatized.

Gated communities in the peri-urban areas of Chengdu and Hyderabad show internal heterogeneities as well. Although the majority of the Indian residents in gated communities of Hyderabad are Hindus, there are also Muslims and Sikhs. In addition to differences of religious affiliation or regional background, one important characteristic that sets apart different residents is property ownership. Similar to the situation in villages where land ownership sets apart the local villagers and in-coming rural migrants, in gated communities the socio-economic status of tenants and house owners can vary greatly. For example, in the high-rise gated community of Mountain View, a large proportion of the flats are inhabited by employees of IT firms in entry-level positions. They rent flats owned by business people or overseas Indians, who bought them as an investment. Often several young bachelors rent one flat together, cohabitating in the complex with the more affluent homeowners.

Interviews in Chengdu's OCT gated community indicated that the residents are not socially homogeneous either. They are mostly well-to-do urban-to-urban migrants, 
working as company employees, civil servants, doctors and so on. A small proportion of the residents are displaced villagers in Jinniu district who are relatively better off than most displaced villagers, who still live in urban villages or the resettlement housing communities. They have used the apartments they obtained as compensation in resettlement communities as leverage access to better housing by either renting or selling them. In the OCT gated community, I also encountered one family of rural migrants engaged in the air conditioning business. After many years of moving from one urban village to another, the family finally rented an apartment in the OCT gated community. Although they appreciated living in a relatively privileged environment, it required more financial effort on their part, compared to urban locals, to maintain a similar living standard. ${ }^{27}$

Compared to the more conspicuous borders between the gated communities and autoconstructed communities discussed in the previous section, the physical boundaries between heterogeneous social groups living within the same residential communities are more implicit, and have more to do with social distinctions. Here, historically constituted norms and the distinction between the haves and have-nots of homeownership play the role of separating, positioning, and ordering the residents in the village of Devenderpally and the gated communities of both Chengdu and Hyderabad.

\section{The vertical cohabitation between migrant tenants and villager landlords}

The planning of Chengdu's global tourism destination and Hyderabad's IT hub have carved out special globalizing spaces. Outside of these spaces, some local villagers have leveraged their land resources to develop rental housing for capturing the real estate surpluses and some of them have started small business. In this section, I especially discuss the assemblages of living together of petty landlords and their migrant tenants. In both Chengdu's urban villages and the multi-story rental houses in Devenderpally village in Hyderabad, the families of the landlords often live on the ground floor, and migrant workers live above them, thus forming a vertical cohabitation.

In all my study sites, migrant tenants outnumbered villager landlords. ${ }^{28}$ Migrant workers pursue mostly manual jobs or small business in Chengdu. In Hyderabad, in addition to manual jobs, most of the rural migrants work in the service sector, while local farmers take up small business supported by the revenue from their rental property. ${ }^{29}$

The migrants in the village of Devenderpally rent rooms from the landowning farmers, either as families living in one room or as several bachelors sharing a room. Many young migrants come as couples, with both working, mostly in the service sectors. In an interview, three migrant women ${ }^{30}$ working as domestic servants, expressed their frustration with the constantly rising rent and the fact that most of their income went towards rent. Although they have a rather friendly relationship with their landlords, their rents were regularly raised. They said that they could not leave the village because other places in the vicinity would demand even higher rents.

Similarly, in Chinese urban villages migrant workers who rent from local farmers in Huaxin village normally work in small business or as manual laborers or service 
workers. Domestic help is not as common in China as in India; most of the service workers work in restaurants, or as security guards or sanitation workers. Mr. $\mathrm{Liu}^{31}$ is an electrician and has lived alone in Huanggang village for six years now, where he rents one room of around 10 square meters. Mr. Liu is very satisfied with the urban village housing since it is cheap enough for him to save some money to send to his family members in the countryside, however with the demolition and redevelopment of the village expected in the near future, he is facing increasing anxiety about finding another apartment the more distant suburbs. With the below-average salaries, urban villages thus serve as a refuge for migrant workers. Only with some extraordinary success in business, allowing them to accumulate savings, could they afford to rent or buy better housing types such as the apartments in resettlement housing communities or even commercial gated communities.

Although relations between landlords and tenants sometimes appear friendly and harmonious, they are intrinsically unequal in both Chengdu and Hyderabad. As the housing shortage is severe, the landlords are in a position to raise the rent frequently, and still find tenants. Migrants have inferior social status and are in a disadvantaged position in the bargaining of rent prices. Oftentimes, the villages in the peripheries are their only options for cheap housing.

The vertical cohabitation of the villager landlords and the migrants exemplifies another configuration of assemblage of living together where different social groups share living spaces but are separated by social categorization of locals and migrants, landlords and tenants, or insiders and outsiders. The spatial patterns of landlords living on the ground floor and residents living on upper floors not only separates the living spaces of the two groups but also allows landlords to easily surveil their migrant tenants as they enter and leave the premises, and observe their behavior, a topic I turn to in the next section.

\section{The relationalities of heterogeneous social groups}

41 In the peri-urban areas of Chengdu and Hyderabad the assembling of heterogeneous social groups and fragmentation arising from boundary building and sociality practices has occurred. I have introduced three configurations of living together as modes of residential cohabitation or coexisting heterogeneity, to use Massey's (2005) term: living together of heterogeneous social groups between gated communities and autoconstructed communities, within the same residential communities and the vertical living together within the same building. The cohabitation of heterogeneous social groups does not indicate a static terrain, but contentious trajectories of assembling processes. Two types of relationalities emerged from my research between and within these assemblages, each with its own paradox. The first is the absence of social interaction despite geographical proximity: different social groups are physically proximate but socialize separately according to norms that often materialize as physical boundaries such as walls, roads, and different floors of the building. The second is unequal interdependence: when forms of interdependence occur between different social groups, it tends to be based on unequal interactions, expressed through attitudes or even discrimination. I suggest that the relationalities between heterogeneous social groups are the key component of the coexisting heterogeneity, and these relationalities and the built environment co-constitute each other. I have 
described the paradoxical proximity and separation in the previous sections, in this section I further elaborate on the new kind of relationalities characterized by unequal interdependence.

The interdependence of residents is materialized in for instance employment and landlord-tenant relations between different social groups. The interdependence between villager landlords and migrant tenants provides affordable housing to migrant workers, and the main source of revenue for many petty landlords. Thus the interdependence of the two groups engenders relations of mutual support. However, my research suggests that the interdependence does not develop into further social solidarity.

In the villages in Chengdu's and Hyderabad's peripheries, the local villager landlords and migrant tenants share living spaces and have many daily interactions. In Chengdu's urban villages, several village landlords mentioned the shared "farmer" identities between villagers and migrants; both are rural hukou holders who have long suffered discrimination in the framework of the rural-urban divide in China. ${ }^{32}$ The shared identities become a source of landlords' compassion towards the migrants, in some cases, within the setting of vertical cohabitation. However, class differences, which are clearly manifested between landlords and tenants in both Chengdu and Hyderabad, sometimes lead to discriminatory attitudes. In Hyderabad's Devenderpally village, I found that the ethnic, cultural and class differences between the villagers and migrants are more prominent factors than shared rural sensibility in determining the modes of interaction. There, the migrants are more often considered as strangers and outsiders. For example, when talking about his migrant tenants, Shankar ${ }^{33}$ complained about the difficulties of living together with them since they have very different mentalities and behaviors. In particular, he complained that the tenants do not keep their rooms tidy and drink alcohol, which he claimed went against the moral standards of a "good" Hindu. Similarly, a daycare school teacher ${ }^{34}$ in Devenderpally village commented that the young women who work in nearby companies and rent rooms in the village are morally corrupt as they stay out late at night and wear inappropriate "Western" clothes.

Migrant tenants are often portrayed by the villager landlords as less cultured, morally corrupt and potentially dangerous in both Chengdu and Hyderabad. In Chengdu's resettlement housing communities, villagers often comment about the migrant tenants' "lack of quality" (suzhi di) or "lack of civility" (bu wenmin). Villagers complain that migrants do not take care of the facilities and environment in the communities, and that they do not keep things clean. Moreover, in both Chengdu and Hyderabad, the villagers often implied that the influx of migrants undermines the security of the neighborhood. When a security issue occurs, especially theft, the migrant tenants are the first to be suspected.

On a broader scale, the employment relations between the middle and upper middle class who work, live and socialize in enclosed enclaves and the residents in autoconstructed communities is central to the prosperity of the globalizing space. In both Chengdu and Hyderabad, gated communities and other special purpose enclaves such as office buildings and malls heavily rely on service workers for domestic help, maintenance workers and security guards. ${ }^{35}$ The spatial patterns of the interspersion of gated communities and auto-constructed communities reflect this interdependence. However, the interdependence is built on highly unequal relations. 

who come from marginalized sections of Indian society, have frequent and prolonged interaction with the socially elite residents of gated communities; however, they may also face severe discrimination. According to several interviewees, domestic workers are commonly accused of stealing from the household where they work, while other male service workers of the enclaves do not face the same degree of stigmatization. In many gated communities, techniques are deployed to surveil and intimidate domestic workers. Domestic workers are not allowed to carry anything except for cell phones and a small purse. They need to carry a particular card assigned to them to pass the gating system, and a specially designed smart phone app is used by residents and security guards in both Mountain View and Ridge Estates to track domestic workers' coming and going. Both have set up an additional checkpoint behind the main gate specially to check the personal belongings of the domestic workers when they enter and leave the gated communities. Normally male security guards are assigned to this task, and the process often involves bodily contacts that are considered particularly humiliating. ${ }^{36}$

The migrants who are at the same time "unskilled" workers and tenants are often stigmatized by gated community residents and the villager landlords who cohabit the urban peripheries with them. The unequal interdependence between heterogeneous social groups is revealed often in aggressive and discriminatory ways. While the cheap labor from migrant workers is highly desirable and contributes to the prosperity of globalizing spaces and the urban economy in general, these individuals are simultaneously undesirable. Following Anagnost, this carries over to the body: their "lower-quality" and "less-cultured" bodies are undesired (Anagnost 2004). The contradictory desirability of the labor and bodies has thus contributed to on the one hand the exploitation of migrant workers through rents or employment relations, and on the other hand uneven distribution and severe surveillance of their bodies.

\section{Conclusion}

Driven largely by state-led globalizing projects, the peripheries of Chengdu and Hyderabad have undergone rapid urbanization and dramatic transformation of the built environment. They have emerged as distinct spaces that bring into proximity middle class gated community residents, villager landlords and migrant tenants who have previously had little or no contact with each other. The aim of this research, of which this paper is a preliminary outcome, is to interrogate the types of sociality generated by this residential cohabitation. This article contributes to enriching the existing literature on social interactions in the urban peripheries (e.g. Garrido 2019; Kundu 2016) by exploring the forms of relationalities between heterogeneous social groups, particularly in relation to the transformation of the material and spatial conditions of residential spaces.

Inspired by the conceptual framework of urban assemblages (Farias and Bender 2010) and coexisting heterogeneities (Massey 2005), I have analyzed the cohabitation of heterogeneous social groups in three main residential settings, all of which are emblematic of the urban peripheries of Chengdu and Hyderabad. I proposed the notion of assemblages of living together to discuss concomitantly the materiality of the built environment and forms of sociality of heterogeneous social groups, to apprehend how

South Asia Multidisciplinary Academic Journal, 26 | 2021 
the materiality and sociality co-constitute each other. I identified three key assemblages of living together associated with three forms of residential cohabitation in the peri-urban areas: the interspersion of autoconstructed communities and gated communities, heterogeneity within the same residential communities and vertical cohabitation of villager landlords and migrant tenants.

I have argued that each of these configurations of residential cohabitation is formed by the interweaving of globalizing forces and various situated local norms that are constituted historically. Thus, categories of religion, caste, gender, regional origins, rural/urban sensibilities, alongside the haves and have-nots of homeownership, play a significant role in separating, positioning, and ordering heterogeneous social groups. However, other types of social processes are also observed, and they interact with the built environment and with deliberate boundary building practices to co-produce forms of sociality. Between and within the various assemblages of living together, I have observed that two main types of relationalities between residents have emerged in the urban peripheries of Chengdu and Hyderabad: 1). different social groups are physically proximate but socialize separately according to certain norms that often materialize as physical boundaries such as walls, roads, and different floors of the building; 2). at times interdependence between different social groups emerges, but it is based on unequal interactions. These observations suggest that residential cohabitation in peri-urban spaces, which brings into close proximity diverse social groups and increases interactions, does not automatically generate new forms of sociality. More research is needed to better understand the conditions under which specific residential patterns and spatial configurations in the built environment give rise to more socially integrated assemblages of living together.

\section{BIBLIOGRAPHY}

Anagnost, A. 2004. “The Corporeal Politics of Quality (Suzhi).” Public Culture 16(2):189-208. doi: 10.1215/08992363-16-2-189.

Balakrishnan, Sai. 2019. "Recombinant Urbanization: Agrarian-Urban Landed Property and Uneven Development in India." International Journal of Urban and Regional Research 43(4):617-32. doi: 10.1111/1468-2427.12790.

Benjamin, Solomon. 2008. "Occupancy Urbanism: Radicalizing Politics and Economy beyond Policy and Programs: Debates and Developments." International Journal of Urban and Regional Research 32(3):719-29. doi: 10.1111/j.1468-2427.2008.00809.x.

Bhan, Gautam. 2016. In the Public's Interest: Evictions, Citizenship, and Inequality in Contemporary Delhi. Athens: The University of Georgia Press.

Bunnell, Tim, and Diganta Das. 2010. "Urban Pulse-A Geography of Serial Seduction: Urban Policy Transfer from Kuala Lumpur to Hyderabad." Urban Geography 31(3):277-84. doi: 10.2747/0272-3638.31.3.277. 
Caldeira, Teresa Pires do Rio. 2000. City of Walls: Crime, Segregation, and Citizenship in São Paulo. Berkeley: University of California Press.

Caldeira, Teresa Pires do Rio. 2017. "Peripheral Urbanization: Autoconstruction, Transversal Logics, and Politics in Cities of the Global South." Environment and Planning D: Society and Space 35(1):3-20. doi: 10.1177/0263775816658479.

Callon, M. 1980. "The State and Technical Innovation: A Case Study of the Electrical Vehicle in France." Research Policy 9(4):358-76. doi: 10.1016/0048-7333(80)90032-3.

Cowan, Thomas. 2015. "Fragmented Citizenships in Gurgaon." Economic \& Political Weekly 50(26/27):63-73.

Das, Diganta. 2015. "Hyderabad: Visioning, Restructuring and Making of a High-Tech City." Cities 43:48-58. doi: 10.1016/j.cities.2014.11.008.

Dupont, Véronique. 2016. "Secured Residential Enclaves in the Delhi Region: Impact of Indigenous and Transnational Models." City, Culture and Society 7(4):227-36. doi: 10.1016/j.ccs. 2015.03.004.

Farias, Ignacio, and Thomas Bender, eds. 2010. Urban Assemblages: How Actor-Network Theory Changes Urban Studies. London; New York: Routledge.

Garrido, Marco Z. 2019. The Patchwork City: Class, Space, and Politics in Metro Manila. $1^{\text {st }}$ ed. Chicago; London: University of Chicago Press.

Gururani, Shubhra. 2020. "Cities in a World of Villages: Agrarian Urbanism and the Making of India’s Urbanizing Frontiers.” Urban Geography 41(7):971-89.

He, Shenjing, Yuting Liu, Fulong Wu, and Chris Webster. 2010. "Social Groups and Housing Differentiation in China's Urban Villages: An Institutional Interpretation.” Housing Studies 25(5): 671-91. doi: 10.1080/02673037.2010.483585.

Hsing, You-tien. 2010. The Great Urban Transformation: Politics of Land and Property in China. Oxford: Oxford University Press.

Jenkins, Rob, Loraine Kennedy, Partha Mukhopadhyay, and Kanhu C. Pradhan. 2015. "Special Economic Zones in India: Interrogating the Nexus of Land, Development and Urbanization." Environment and Urbanization ASIA 6(1):1-17. doi.org/10.1177/0975425315585426.

Kanbur, Ravi, and Juzhong Zhuang. 2013. "Urbanization and Inequality in Asia.” Asian Development Review 30(1):131-47. doi: 10.1162/ADEV_a_00006.

Keil, Roger. 2017. Suburban Planet: Making the World Urban from the Outside In. $1^{\text {st }}$ ed. Medford, MA: Polity.

Keil, Roger. 2018. “Extended Urbanization, 'Disjunct Fragments' and Global Suburbanisms.” Environment and Planning D: Society and Space 36(3):494-511. doi: 10.1177/0263775817749594.

Kennedy, Loraine. 2007. "Regional Industrial Policies Driving Peri-urban Dynamics in Hyderabad, India.” Cities 24(2):95-109. doi: 10.1016/j.cities.2006.06.001.

Kennedy, Loraine, and Ashima Sood. 2019. "Outsourced Urban Governance as a State Rescaling Strategy in Hyderabad, India.” Cities 85:130-39. doi: 10.1016/j.cities.2018.09.001.

Kochan, Dror. 2015. "Placing the Urban Village: A Spatial Perspective on the Development Process of Urban Villages in Contemporary China." International Journal of Urban and Regional Research 39(5):927-47. doi: https://doi.org/10.1111/1468-2427.12287. 
Kundu, Ratoola. 2016. "Making Sense of Place in Rajarhat New Town: The Village in the Urban and the Urban in the Village." Economic \& Political Weekly 51(17):93-101.

Latour, Bruno. 1987. Science in Action: How to Follow Scientists and Engineers Through Society. Harvard University Press.

Massey, Doreen B. 2005. For Space. $1^{\text {st }}$ ed. London; Thousand Oaks, CA: SAGE Publications Ltd.

Ong, Aihwa, and Stephen Collier, eds. 2004. Global Assemblages. $1^{\text {st }}$ ed. Malden, MA: WileyBlackwell.

Prasad, Sheela, and C. Ramachandraiah. 2008. "The Makeover of Hyderabad: Is It the 'Model' IT City?" In High-tech Urban Spaces: Asian and European Perspectives, edited by C. Ramachandraiah, A.C.M.V. Westen, and S. Prasad. New Delhi: Manohar Publishers.

Qin, Bo. 2015. “City Profile: Chengdu.” Cities 43:18-27. doi: 10.1016/j.cities.2014.11.006.

Ren, Xuefei. 2021. “Suburbs and Urban Peripheries in a Global Perspective.” City \& Community, February. doi: 10.1111/cico.12505.

Roy, Ananya. 2009. "Why India Cannot Plan Its Cities: Informality, Insurgence and the Idiom of Urbanization.” Planning Theory 8(1):76-87. doi: 10.1177/1473095208099299.

Roy, Ananya. 2011. "Slumdog Cities: Rethinking Subaltern Urbanism." International Journal of Urban and Regional Research 35(2):223-38. doi: https://doi.org/10.1111/j.1468-2427.2011.01051.x.

Sack, Robert David. 1986. Human Territoriality: Its Theory and History. Cambridge [Cambridgeshire]; New York: Cambridge University Press.

Sandercock, Leonie. 2000. "When Strangers Become Neighbours: Managing Cities of Difference." Planning Theory \& Practice 1(1):13-30. doi: 10.1080/14649350050135176.

Sassen, Saskia. 2006. "Toward an Alternative Narrative about Globalization: Global Cities and Survival Circuits.” Cahiers Du Genre 40(1):67-89. doi: 10.3917/cdge.040.0067.

Shen, Jie, and Fulong Wu. 2017. "The Suburb as a Space of Capital Accumulation: The Development of New Towns in Shanghai, China." Antipode 49(3):761-80.

Sood, Ashima, and Loraine Kennedy. 2020. "Neoliberal Exception to Liberal Democracy? Entrepreneurial Territorial Governance in India." Territory, Politics, Governance 8(1):23-42. doi: 10.1080/21622671.2019.1687323.

Swerts, Elfie, and Éric Denis. 2015. “Megacities: The Asian Era.” Pp. 1-28 in Urban Development Challenges, Risks and Resilience in Asian Mega Cities, Advances in Geographical and Environmental Sciences, edited by R.B. Singh. Tokyo: Springer Japan.

Upadhya, Carol. 2020. "Assembling Amaravati: Speculative Accumulation in a New Indian City." Economy and Society 49(1):141-69.

Webster, Douglas R., Jianming Cai, Larissa Muller, and Binyi Luo. 2004. "Peri-Urbanization in Chengdu, Western China: From 'Third Line' to Market Dynamics.” Working Paper, The AsiaPacific Research Center, Standford University, Stanford, CA. Retrieved April 21, 2021 (https:// aparc.fsi.stanford.edu/publications/ periurbanization_in_chengdu_western_china_from_third_line_to_market_dynamics). Wu, Fulong. 2010. "Gated and Packaged Suburbia: Packaging and Branding Chinese Suburban Residential Development.” Cities 27(5):385-96. 
Wu, Fulong. 2020. "Scripting Indian and Chinese Urban Spatial Transformation: Adding New Narratives to Gentrification and Suburbanisation Research." Environment and Planning C: Politics and Space 38(6):980-97. doi: 10.1177/2399654420912539.

Wu, Fulong, Fangzhu Zhang, and Chris Webster. 2013. "Informality and the Development and Demolition of Urban Villages in the Chinese Peri-urban Area." Urban Studies 50(10):1919-34. doi: $10.1177 / 0042098012466600$.

Xie, Liubing, Elfie Swerts, and Denise Pumain. 2018. "Economic Development Zones and Urban Growth in China." Cybergeo : European Journal of Geography. doi: 10.4000/cybergeo.30143.

Young, Iris Marion. 2011. Justice and the Politics of Difference.

Zhang, L., Simon X. B. Zhao, and J. P. Tian. 2003. "Self-Help in Housing and Chengzhongcun in China's Urbanization." International Journal of Urban and Regional Research 27(4):912-37. doi: https://doi.org/10.1111/j.0309-1317.2003.00491.x.

Zhang, Li. 2010. In Search of Paradise: Middle-class Living in a Chinese Metropolis. $1^{\text {st }}$ ed. Ithaca, NY: Cornell University Press.

Zhou, Xueguang, and Yun Ai. 2016. "Bases of Governance and Forms of Resistance: The Case of Rural China." Pp. 443-60 in The SAGE Handbook of Resistance, edited by D. Courpasson and S. Vallas. Thousand Oaks, CA: SAGE Publications Ltd.

\section{NOTES}

1. However, I do not suggest that informal, self-built settlements are unplanned development; as Roy (2009) argues, informality is an integral part of official planning in regulating and allocating land resources.

2. This research was carried out as part of my Master's degree at the École des Hautes Études en Sciences Sociales, Paris, and the fieldwork was partly supported by a travel grant from the Asian Studies Master's program. I am grateful to Sarath and Syam for assistance with some of the interviews in Hyderabad.

3. To protect interviewees' privacy, all their names are replaced by pseudonyms, and most of the specific place names are also replaced by pseudonyms.

4. Developed by French sociologists Latour (1987) and Callon (1980).

5. Borrowing anthropologist Li Zhang's (2010) phrase in her monograph In Searching of Paradise.

6. Following Robert David Sack (1986), human territoriality is "the attempt by an individual or a group to affect, influence, or control people, phenomena, and relationships, by delimiting and asserting control over a geographic area" (p. 19).

7. And it marked the city's success in this regard by hosting the $22^{\text {nd }}$ General Assembly of the United Nations World Tourism Organization in 2017; see for example a report from China Daily: https://www.chinadaily.com.cn/m/chengdu/wenjiang/2017-10/20/content_34015480.htm

8. Overseas Chinese Town Co., Ltd is under the direct control of State-Owned Assets Supervision and Administration Commission of the State Council; the company has developed amusement parks, hotels, and gated communities in many Chinese cities.

9. The oxymoron of a state-owned developer named Overseas Chinese Town, hereafter OCT, suggests the particularity of real estate development and the mode of globalization in China. The characteristics of being "international" or "overseas" are perceived by Chinese society as modern and advanced. The Chinese state and its state-owned companies have appropriated the discourse of globalization, modernity, and "world-class" into their development agenda, creating a kind of globalizing project without the direct participation of foreign capital. In contrast to the past, 
when foreign direct investment was the major driver of the country's modernization and globalization processes, in recent years, it is the state and domestic companies that carry the banners of globalization and increasingly play leading roles in the making of world-class cities.

10. However, some of the village collectives or individual households still resist the redevelopment project. For example, some households in Fansheng villages were still staying put at the time the fieldwork was conducted. They are the ones who are not satisfied with the compensation the government provided and chose to stay and continue negotiations in hopes of better compensation packages.

11. Unless otherwise mentioned, photographs were taken by the author.

12. The city of Chengdu is not required by law to provide housing for rural migrants, because their household registration (hukou) status is not "urban." Consequently, they must find cheap housing.

13. Other urban villages in the peripheries of Jinniu district also serve either the function of accommodating rural migrants or supporting petty commercial activities, and in some cases a combination of both. Fansheng village was largely comprised of stand-alone rental houses that are extended from scattered farmhouses. The houses and yards of Zhuwa village are mostly rented by printing, paper manufacturing, alcohol making, building material manufacturing factories, and so on, and some companies also rent them as warehouses.

14. High-school girl who lives in Huaxin village in Chengdu, interviewed on January 6, 2019.

15. Elderly barbershop owner in Huaxin village in Chengdu, interviewed on January 6, 2019.

16. Since the start of the Huaxin village redevelopment processes, the monthly fairs are no longer organized.

17. Elder retired resident of [either "an" or "the"] OCT gated community in Chengdu, interviewed on 16 Jan. 2019.

18. Information from multiple interviewees.

19. According to a ranking of all primary schools in Jinniu district (https://www.chinaxqf.com/ gopschool/510106.html), Renbei primary school is ranked the third among 52 schools; on the other hand, Fansheng primary school, which recruits mostly villagers' children and migrant children, is ranked 43th.

20. Young housewife in OCT gated community, age 23, interviewed on January 22, 2019.

21. Anagnost argues that the body of the urban, middle-class only child is fetishized as the site for the accumulation of value embodied in the quality (suzhi) of a person, while the rural migrant exemplifies its apparent absence.

22. Interviewed on March 1, 2019.

23. A member of the panchayat in Devenderpally village, male, age 39, interviewed on February 23, 2019.

24. And in the Chinese case, the hukou (household registration) system has institutionalized the rural-urban divide.

25. See Balakrishnan (2019), Gururani (2020), and Upadhya (2020) among others who demonstrate that the urban real estate market in India is built on a prior uneven agrarian land market shaped by land-based caste/class relations.

26. A middle-aged herder in Devenderpally village, male, interviewed on 10 March 2019.

27. Mr. Wang who lives in the OCT gated community, interviewed on January 22, 2019.

28. Both the migrant workers and the local villagers were originally farmers, what sets them apart is whether their land could be capitalized in the rapid urbanization process. With the land locating in the rapidly urbanizing areas, the villagers in Devenderpally villages or Chinese urban villages turned themselves into petty landlords and entrepreneurs, however, the farmers in remote regions could only leave their land behind and rent from other villagers' autoconstructed housing in urban peripheries to benefit from the better-paid employment opportunities in cities. 
29. For example, Shankar, a shopkeeper and landlord in Devenderpally (male, interviewed on February 25,2019$)$ has also started to sell water barrels in the village, and a member of the panchayat has started a building materials business. The villagers turned entrepreneurs have accumulated capital from selling land and building autoconstructed rental houses, and then running small businesses. However, some villagers who have not managed the wealth from selling land well in the first place, have to work as security workers or auto drivers like the migrants.

30. Migrant women working as domestic workers, interviewed on February 24, 2019.

31. Migrant worker working as a technician, age 40, interviewed in Huanggang village on January $24,2019$.

32. For example, Mrs. Xie, 67, a resettled villager living in a resettlement community, interviewed on January 23, 2019, said to me, "Migrant workers are like us. Before we also were farmers, after all we are the same... We live side by side harmoniously. We depend on them and they depend on us... Honestly, although our apartments are not that good, they came to us because they want cheap housing, and at the same time we want some revenue. Like this, both sides benefit. If they didn't come to rent our apartments, our life would be difficult."

33. Shankar, a shopkeeper and landlord in Devenderpally, male, interviewed on February 25, 2019.

34. Daycare school teacher in Devenderpally village, female, interviewed on February 25, 2019.

35. Sassen's (2006) notion of survival circuits is relevant to reflect on the relations between global cities and the globalizing unskilled workers, particularly low-wage women workers.

36. This information about body searches of domestic workers was not directly communicated to me, a male foreign researcher, in my interviews with the domestic workers. Rather it came from a focus group discussion with four expatriate housewives of Australian, American, and French nationality in Ridge Estates, on March 14, 2019. According to these women employers, the domestic workers complained constantly about the aggressive "preventive measures" imposed on them by the gated community.

\section{ABSTRACTS}

At a time when China and India are urbanizing rapidly, the transformation of the urban peripheries has brought into close proximity social groups who previously had little or no contact with each other. In this article, I approach the question of residential cohabitation by investigating similar types of residential areas in Chengdu and Hyderabad, which are emblematic of those found in the urban peripheries: autoconstructed communities and gated communities. Inspired by research on urban assemblages, and on the basis of fieldwork conducted in each setting, I introduce the notion of "assemblages of living together." I have identified three key assemblages associated with three distinct forms of residential cohabitation: the interspersion of autoconstructed communities and gated communities, heterogeneity within the same residential communities, and vertical cohabitation of villager landlords and migrant tenants. Between and within the various assemblages of living together, I have observed two main types of relationalities between residents: different social groups are physically proximate but socialize separately according to certain norms that often materialize as physical boundaries such as walls, roads, and different floors of the building; at times interdependence between different social groups emerges, but it is based on unequal interactions. 
INDEX

Keywords: residential cohabitation, peri-urbanization, autoconstruction, gated community, rural migrant

\section{AUTHOR}

\section{LIUBING XIE}

PhD Student, University of California, Berkeley 